\title{
パルス立ち上がり時間による放電発光色の制御
}

\author{
専門会員 竜子 雅俊* 藤野 達士* 佐藤 輝男* \\ 久保寔** 専門会員 板谷 良平**
}

\section{A Method to Change Luminous Color of a Positive Column by Controlling Pulse Rise Time}

\author{
Masatoshi Ryohko (Fellow Member) Tatsushi Fujino Teruo Satoh \\ (Department of Electrical Engineering, Akashi Technological College)
}

Makoto Kubo and Ryohei Itatani (Fellow Member)

(Department of Electronics Engineering, Faculty of Engineering, Kyoto University)

\begin{abstract}
This paper discribes a new method to change luminons color of a positive column of a low pressure $\mathrm{Hg}$ - Ne discharge lamp.

Pulses of triangle wave form, whose width, rise time and recurrence frequency had been changed widely, mere applied to discharge lamps of $10 \mathrm{~cm}$ in interelectrode distance and from $1 \mathrm{~cm}$ to $5 \mathrm{~cm}$ in diameter.

The color of the positive column could be controlled electronically from blue to red by varying pulse rise time only, heving kept pulse voltage, pulse width and pulse recurrence frequency constant.

In general, when the pulse rise time is shorter than $10 \mu \mathrm{s}$, the color is red and, on the contrary, it is blue when the rise time is longer than $150 \mu \mathrm{s}$.

The optimun recurrence frequency, at which the change of color from red to blue and vice versa is favorable by varying only the pulse rise time, has such a relation with diameter of discharge lamp that $\mathrm{f}=210 /(2 \mathrm{R}) \mathrm{Hz}$ and is insensitive to change of the pulse width.
\end{abstract}

\section{1. は じめに}

視覚を通して情報を伝達する場合，多色表示することは見る者 に印象強く訴えるだけでなく，伝達情報の量の增大ならびに質の 向上をももたらすので，単一色表示に比べてきわめて有効であ る. 種々の表示装置や光源汇いてても，この多色化への努力は行 なわれてきている。しかし現段階では，ネオンサインや電光サイ ンのように色の異なる光源（光点）を並置する方法，または舞台 照明光源のように，フィルタの切り換えによる方法のいずれかで ある．前者においては光の色を変えると光の位置が変わる．後者 においては，機械的方法では速応性を欠き，電子的方法には液晶 を用いる方法があるが速度は早くないまた，いずれの場合にも 光の色を連続的に変化させることはできない，

これに対し，筆者らは 1 個の放電管の発光色を外部点灯回路で 電子的に制御する “可変色放電” の研究を進めてきだ 3).

\footnotetext{
* 明石工業高等専門学校電気工学科

**京都大学工学部電子工学教室

この論文の一部は，電気関係学会関西支部連合大会 (昭和53年11月) G13-9て

藤野が，照明学会全国大会（昭和54年 4 月）23で竜子がそれぞれ講演している.
}

これは原理的にパルス放電であって，パルスの繰り返し周期な らびに，パルス幅を変えることによって発光色を変えるものであ る.しかし，周期やパルス幅を大幅に変える方法は色の变化とと もに輝度が変化するので実用的でなく，末たこの放電を（現在単 一色表示である）プラズマ・ディスブレイに㐫用することを考え ると周期は一定でなければならず，パルス幅も大きく変えるのは 好ましくないこの二つのパラメータ以外に発光色を制御できそ らな因子としては，パルスの波形が考えられる。

筆者らは放電に三角パルスを使用し，その立ち上がり時間を変 えることによって発光色を制御する方式について実験を行ない, 上述の方法と同様, 可変色放電が可能なことを確かめた. 必要と される長さ・径の放電管に対して, 封入ガス死, 電源電圧, ハル ス幅, 繰返し周波数など, 他の選択の許される放電諸因子が発光 色にどのよらに影響し，かつそれらの因子をどのような值に設定 すべきかについても実験を行なった。

本論文は，パルス繰返し周波数とパルス幅を一定にしたままで パルス波形だけによって放電の発光色を制御する方法についての 研究結果を述べたものである。この方法では周波数とパルス幅を 変えずに発光色を制御できるだけでなく，色を変えてす放電陽光 
柱の輝度は汪とんど変わらないので, 可変色放電の垁際的な利用 およびプラズマ・ディスプレイへの応用にたいへん有効である.

\section{2. 可変色放電の原理と発光色制御方式}

放電中の電子の運動エネルギーを外部回路で電子的に制御する ことにより，発光色を変えるのが可変色放電であるが，その原理 について詳しいことは省略する (文献 1 参照). $\mathrm{Ne}$ と $\mathrm{Hg}$ とを 混合封入した放電管にパルス電王を印加し，陽光柱電界の時間的 变化を利用して発光色を制御するパルス制御方式には, 次の 3 と 打りが考えられる。

\section{1 パルス幅による制御}

図 1（a）のようなパルスで放電させる場合，立ち上がり部分 （A部）では赤色が，後のほうのBの部分では青色が原則的には 発光する. 周期 $T$ を適当な值に保ち，パルス幅 $\tau$ を小さくすれば $\mathrm{A}$ 部分の占める割合が大きくなるので発光色は赤色となり, 逆に $\tau$ を大きくすれば $\mathrm{B}$ 部分の占める割合が大きく, 発光色は青色と なる.この場合, 赤色発光時の duty factor $\tau / T$ は青色発光時 のそれょりも小さいので，電圧を一定とするならば赤色は青色よ り暗い。

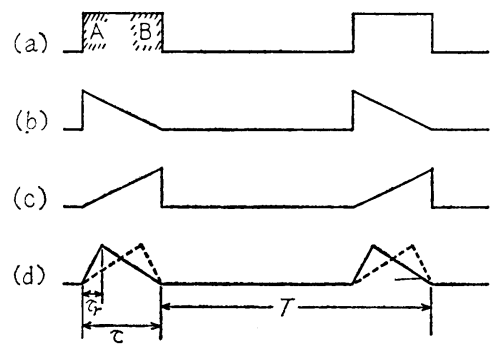

图1名種ハル下波形

\section{2 繰返し周期（周波数）による制御}

パルス幅 $\tau$ を小さな值（一定）にしておいて，周期 $T$ を大きく すると放電休止時間 $T$ 一 てが大となり，管内の消イオンが進行す るので $\mathrm{A}$ 部分での電界は大きく，したがって発光色は赤色とな る. 逆にTを小さくすると残留イオンが多くなるために $\mathrm{A}$ 部分で の電界は大きくならず, 発光色は青色となる.この場合にも赤色 発光に対する $\tau / T$ は青色発光のそれよりも小さいので, 2. 1 同 様, 赤色は青色よりも暗いことになる.

\section{3 パルス立ち上がり時間による制御}

図1（b)，（c）のように，パルス立ち上がり時間が異なる2 種類の三角パルスで放電させる場合について考えてみる．立ち上 がりの急峻な(b)の八形パルスでは，立ち上がり部分で赤色が発光 した後は電流が減少し，Bに相当する部分での青色発光が抑えら れるので発光色は赤色となる，一方，立ち上がりの緩やかな(c)の ヘ形パルスでは急激な電圧印加が行なわれないので, 立ち上がり 部分での電界は大きくならず, 赤色発光が抑兄られ発光色は青色 となる。そして図1（d）のよらにパルスの立ち上がりを連続的 に変えると，発光色は赤と青の間を連続的に变化するものと考兄 られる。このとき周期 $T$ およびパルスすそ幅てを一定にしておけ ば， $\tau / T$ は一定となるので，発光色が変化しても輝度はほとん ど一定となる. 輝度を変えないで発光色が変えられるということ は，実用上たいへん好都合である.しかも周期 $T$, 幅 $\tau$ は共に一 定のままでよいので, マトリックス電極を用いるプラズマ・ディ スプレイヘの応用も原理的に可能となる.
このようにハルス立ち上がり時間による制御う式は，回路が多 少複雑化するものの利点が多い。

\section{3. 実験装置および実験方法}

\section{1 放 電管}

実験に使用した放電管は基本的には図 2 に示すような構造で， 直円筒のガラス管内に 1 対の平板電極を対向させたものである. 管径汸いて主として, $1 \mathrm{~cm} \phi, 1.95 \mathrm{~cm} \phi, 2.73 \mathrm{~cm} \phi, 4.7$ $\mathrm{cm} \phi$ の 4 種類とした. 電極間距離はいずれも $10 \mathrm{~cm}$ である. 放 電管には十分な量の $\mathrm{Hg}$ と, 所定の圧力の $\mathrm{Ne}$ とが封入されて いる. $\mathrm{Ne}$ の圧力は主として 8，16，32，64 Torr について実験 を行なった，その他にも数種の管径，封入圧の放電管を作って補 助的な実験に供した．特に電極間距離を任意に変える場合には可 動電極放電管を使用した。

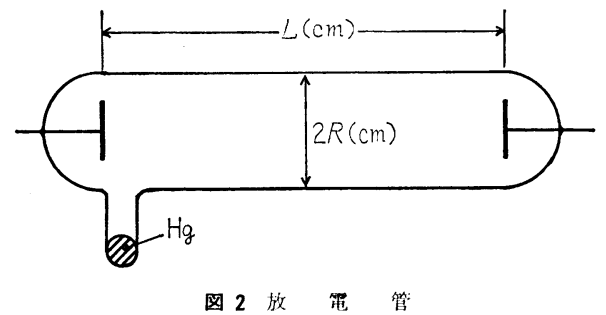

3.2 点灯回 路

図 3 （a）に示すのが基本点灯回路で, 直流電源, 放電管, トラ ンジスタの三つが直列に接続されている。電源電在はぜから $2,000 \mathrm{~V}$ まで変兄られる. ハ八ス発生回路で周期・幅・立ち上が りを設定された三角パルスをトランジスタのべースに入力し，放 電の発光色を制御する. そしてこのべース電流の振幅によって放 電管の輝度を調節する. この回路では放電管の電極はどちらも接 地されないので, 管電圧の波形観測には不便である. 電圧波形を 観測する場合には同図 (b)の回路を用いた.

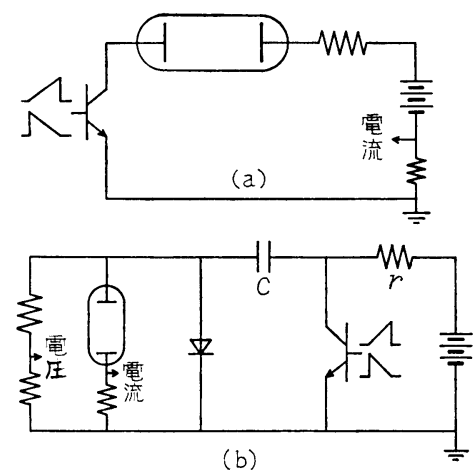

图 3 点灯回路

\section{3 実験方法と光学測定}

放電管内の $\mathrm{Hg}$ 蒸気圧は管壁温度によって变動するので, 放電 管全体を恒温槽に入れて温度管理しながら実験を行なった．温度

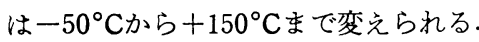

スペクトルの測定には, 図 4 に示すように回折格子モノクロ メータを使用し, 光電子増倍管の出力は増幅器を通してシンクロ スコープで波形を観測するとともに，平滑増幅回路を通して分光 分布をペンレコーダに記録する. この分光分布から計算によって

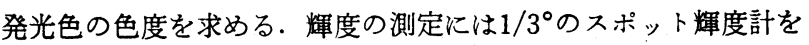
用いた。 


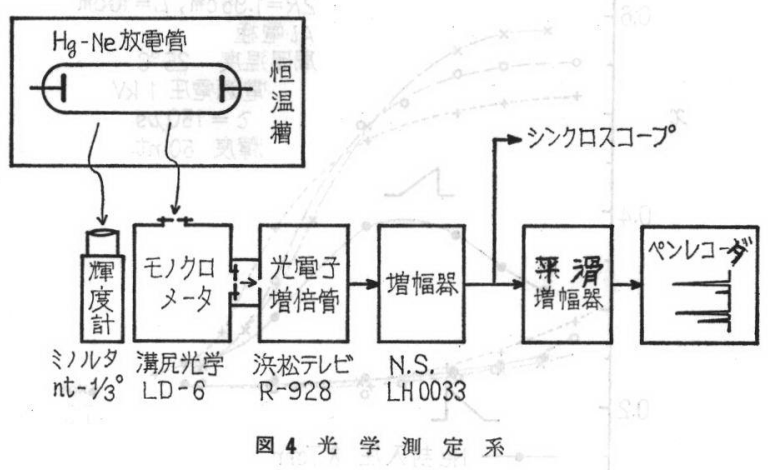

\section{4. パルス立ち上がり時間と発光色}

立ち上がりの急峻なパルスで放電させると発光色は赤色とな り，立ち上がりの緩やかなパルスでは青色になるであろうこと は前に述べた，そのことを確かめるため，繰返し周波数を 100 $\mathrm{Hz}$ ，パルスすそ幅を $300 \mu \mathrm{s}$ に保っておいて，立ち上がり時間を

(a)

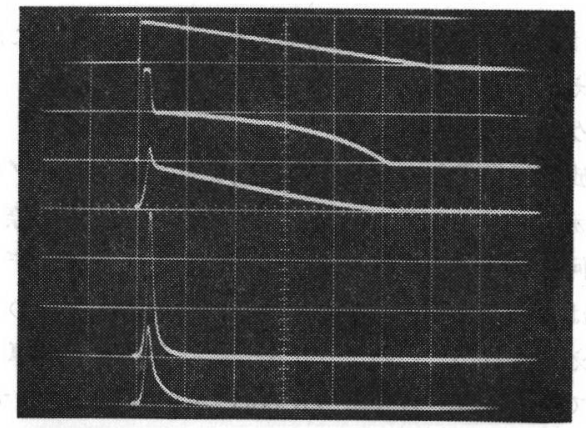

(b)

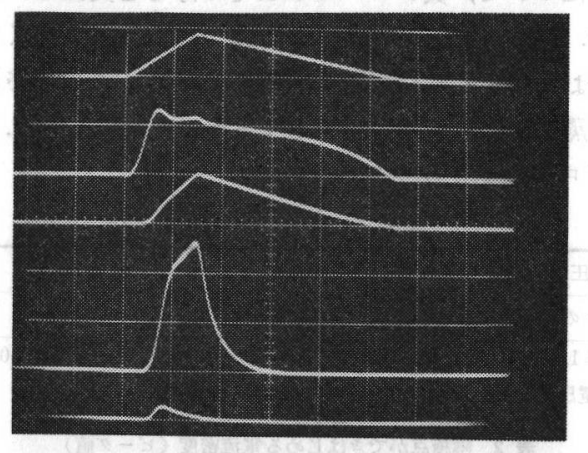

(c)

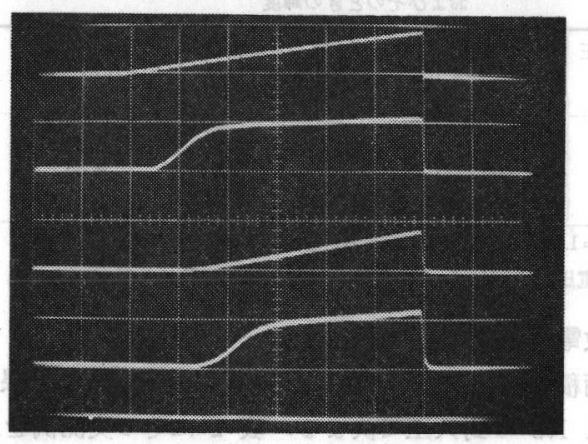

図 5 電圧・電流・発光波形

(a)(b)(c)共 横軸 $50 \mu \mathrm{s} / \mathrm{div}$, 縦軸上か $5(1)$ ベース 電流 (ピークー定), (2) 放電管電压 $500 \mathrm{~V} / \mathrm{div}$, (3) 放電電流 $500 \mathrm{~mA} / \operatorname{div}$ (4) $435.8 \mathrm{~nm} \mathrm{HgI \text {, }}$

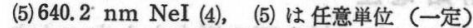
$2 R=1.95 \mathrm{~cm}, \mathrm{~L}=10 \mathrm{~cm}, \mathrm{Ni}$ 電極, $\mathrm{Ne}$ 封入圧 15 Torr, 周囲温度 $20^{\circ} \mathrm{C}$, 電源電圧 $1 \mathrm{kV}, \mathrm{f}=$ $100 \mathrm{~Hz}, \tau=300 \mu \mathrm{s}, \tau_{r}:$ (a) $0.7 \mu \mathrm{s}$, (b) $75 \mu \mathrm{s}$, (c) $300 \mu \mathrm{s}$ ，輝度 $50 \mathrm{nt}$
$0.2 \mu \mathrm{s}$ から $300 \mu \mathrm{s}$ まで变えて実験を行なった．

まず 図 5 に放電電圧, 電流, 発光スペクトルなどの波形を示 す. 図 5 (a)，（b)，（c）はパルス立ち上がり時間がそれぞれ， $0.7 \mu \mathrm{s}, 75 \mu \mathrm{s}, 300 \mu \mathrm{s}$ の場合で, 各図共上から順に点灯制御卜 ランジスタのベース電流, 放電管電圧, 放電電流, HgI 435.8 $\mathrm{nm}, \mathrm{NeI} 640.2 \mathrm{~nm}$ の波形を示す. 立ら上がりが緩やかになる につれて Ne の発光が弱まるとともに, $\mathrm{Hg}$ の発光が強くなって いくことがわかる. このときの発光色と陽光柱輝度の変化の様子 を図 6 亿示す.

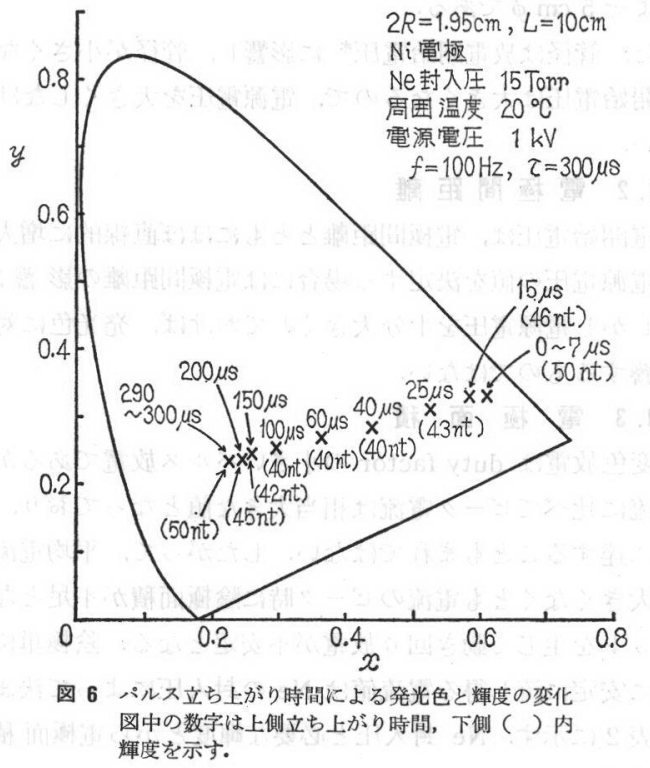

立ら上がりが急峻であれば発光色は赤色であるが，立ち上がり が緩やかになるにつれて青色となっていき，発光色は赤と青の間 を連続的に変化することが確かめられた．立ち上がり時間が 10 $\mu \mathrm{s}$ ぐらいまでは発光色は変化せず, $10 \mu \mathrm{s}$ から100 $\mu \mathrm{s}$ ぐらいま での影響がきわめて大きい.すそ幅の半分の $150 \mu \mathrm{s}$ から最後 300 $\mu \mathrm{s}$ までの立ち上がりの影響は小さく, 発光色はわずかしか変化 しない。この間, 発光色は色度図上で赤と青の間を直線的に移動 している.

一方, 輝度は立ち上がりの両極端の赤色と青色で $50 \mathrm{nt}$ である のに対し, 立ち上がりの中ぐらいな中間色の領域ではやや低下 し, 40〜100 $\mu \mathrm{s}$ で最小の $40 \mathrm{nt}$ となっている. しかし，この程度 の変動は実用上はほとんぞ問題にならないと考えられる.

ここで重要なのは両端の発光色の色度差である. 中間の色を出 すのは容易である. したがって, この赤・青両端の色度差 (変色 幅）ができるだけ大きくなるように, $\mathrm{Ne}$ 封入圧，電源電圧，次 ルス幅, 繰返し周波数などの諸因子を設定しなければならない.

\section{5. 発光色に影響を及ぼす放電諸因子とその適性値}

放電の発光色に関係する因子には, 製作された放電管に付随し たものと点灯時に回路側で選定できるものとがある。パル立ち 上がり時間だけで発光色を制御しょうとする場合に, これらの放 電諸因子が発光色にどのように影響し，かつそれらの值をどう設 定すればよいかについて実験結果をもとに述べていく．

\section{1 放電管に係わる因子}

放電管側に係わる因子としては，(1)管径，(2)電極間距離，(3)電 極面積, (4) $\mathrm{Ne}$ 封入圧, (5) $\mathrm{Hg}$ 蒸気圧の五つが挙げられる. これ らのらち，(1)と(2)は文字など表示上の“needs”から決まるもの 
である．これに対応して(3)，(4)および回路側の因子の值を選定す ることになる。

\subsection{1 管径}

管径は消イオンの速度に大きな影響をもつので, 繰返し周波数 の最適值に影響するはずである. 事実, 実験によってこのことを 確かめその関係式を求めた. 詳細は5.2.4 繰返し周波数の項で述 べるが，それによると管径を大きくすると繰返し周波数を小さく しなケればならない，人間の目は $40 \mathrm{~Hz}$ 以下ではちらつきを感じ るので, 使用できる放電管の径には上限があることになり，それ は㧍よそ $5 \mathrm{~cm} \phi$ である。

また，管径は放電開始電圧*に影響し，管径が小さくなるほど 放電開始電圧は大きくなるので，電源電圧を大きくしなければな らない.

\section{1 .2 電極間距 離}

放電開始電圧は, 電極間距離とともにほぼ直線的に増大するの で，電源電圧の值を決定する場合には電極間距離の影響は大き い、しかし電源電圧を十分大きくしておけば，発光色に対して直 接影響するものではない。

\subsection{3 電 極 面 積}

可変色放電は duty factor の小さいパルス放電であるから, 平 均電流に比べてピーク電流は相当大きな值となっており, 数アン ペアに達することもまれではない,したがって, 平均電流はそれ ほど大きくなくとも電流のピーク時に㓌極面積が不足となれば, スポットを生じて動き回り放電が不安定となる。陰極単位面積当 たりに安定に流し得る電流值は $\mathrm{Ne}$ の封入圧によって決まる。一 例を表 2 に示す. $\mathrm{Ne}$ 封入压と必要な輝度とから電極面積を決め ることになる。

\subsubsection{Ne 封入 圧}

$\mathrm{Ne}$ 封入压の選定に際しては, 発光色のほか㴔グロ一の厚 さ, 放電電流 (輝度) の上限, 放電開始電圧を考虑する必要があ る.

\section{(1) 発 光 色}

$\mathrm{Ne}$ 封入斥は, $\mathrm{Ne}$ 原子数および $\mathrm{Ne}$ と $\mathrm{Hg}$ の分圧比を決定 し，消イオンの速度にも影響するはずであるから，発光色に対し ても当然影響を及ぼすことが予想される，そこで， $\mathrm{Ne}$ 封入压が 8 Torr から 64 Torr までの 4 本の放電管（管径 $1.95 \mathrm{~cm} \phi$ ）を使 用し，繰返し周波数を $40 \mathrm{~Hz}$ から $2 \mathrm{kHz}$ まで変えて発光色の変 化を調べた。 パルス幅は八形, 人形共に $150 \mu \mathrm{s}$ 一定とし。陽光柱 輝度は50 nt一定とした，その結果を図 7 に示す. Ne封入王を パラメータとし，横軸に周波数，繸軸に CIE 色度図の $x$ 座標を とってある. 本論文で扱っている可変色放電は䞑青変色であ り,図 6 の例の上うに, 発光色は色度図上の決まった直線 $(y \simeq$ $0.247 x+0.180)$ に沿って動く.したがって発光色は $x$ 座標たけ で決まるといえる.

イ形パルスによる発光色には， Ne 封入圧による差異がほとん ぞないが，人形パルスによる発光色のほうは， $x$ の最大值が圧力 によって多少異なっていて，16，32，64，8 Torr の順に大きい. すなわち, 十数 Torr 以上では $\mathrm{Ne}$ 封入圧の小さいほうが赤の 発光色が良く, 入形へ形の色度差も大きい. しかし, 発光色一周 波数特性に対する $\mathrm{Ne}$ 封入圧の影響については，あまりはっきり

\footnotetext{
* パルス電压の波高値を徐々に上げていって放奄しはじめるときの值を指す. 今回の実験では周波数は $40 \mathrm{~Hz}$ 以上，ハルス幅は数十 $\mu \mathrm{s}$ 以上であるが，この螌 畔では実測の結果，周波数やバルス幅によってほとんど変わらず，值流放電の開 始電王とほぼ同じ值であった。
}

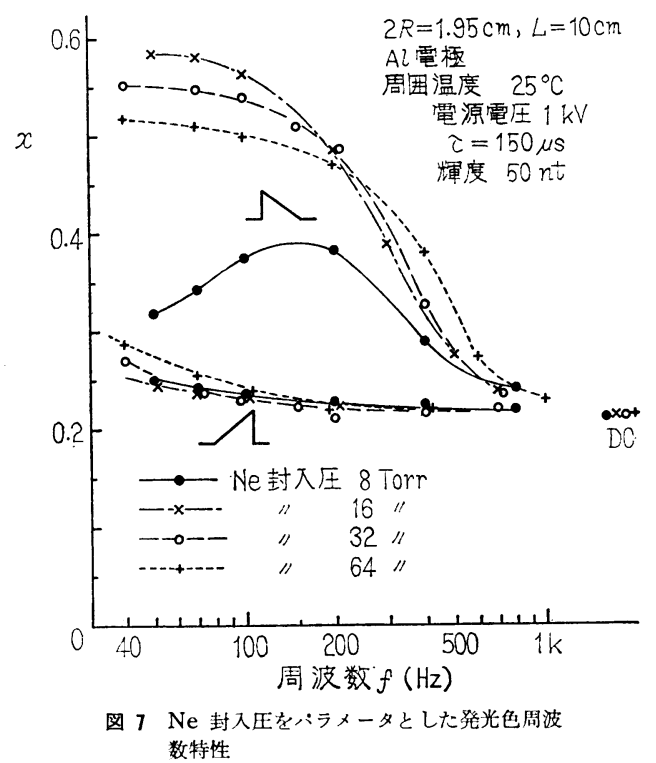

した傾向は示していない，実用上， $\mathrm{Ne}$ 封入圧の違いによって周 波数を変える必要はほとんどない。

\section{(2) 負グローの厚さ}

可変色放電で発光色の変わるのは陽光柱であり, 負グローの色 は $\mathrm{Ne}$ の赤橙色のまま変わらない.したがって使用に際してはこ の部分は何らかの方法で隱さなければならない，放電ディスプレ イなどでは，負グローを見えなくするには構造に多少の工夫を要 すると考えられるが，このような場合には負グローの厚さはたい へん重要である. Ne 封入圧が 8 Torr から64 Torr をでの 4 種 類の場合について，負グローの抢よその厚さを実測した結果を表 1 に示す. $\mathrm{Ne}$ 封入圧が大きくなるにつれて急激に薄くなり，64 Torr ではほとんど測定できないほどである．この厚さは管壁温 度 $\left(\mathrm{Hg}\right.$ 蒸気压)によっても大きく変わり, $150^{\circ} \mathrm{C}$ （2.8 Torr） では負グローは見えなくなる。

表 1 負グロ一の厚さ

\begin{tabular}{|c|c|c|c|c|c|c|}
\hline $\mathrm{Ne}$ 封入民: & \multicolumn{2}{|c|}{ (Torr) } & 8 & 16 & 32 & 64 \\
\hline \multicolumn{3}{|c|}{ 負グローの厚さ (mm) } & 10 & 3 & 0.3 & $\sim 0.1$ \\
\hline \multicolumn{7}{|c|}{ 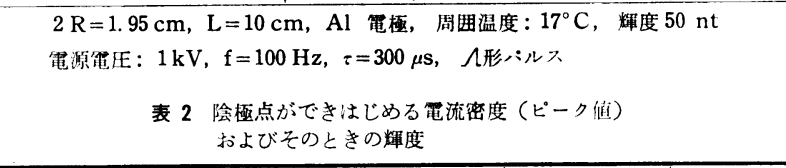 } \\
\hline $\begin{array}{l}\text { Ne 封入匠 } \\
\text { (Torr) }\end{array}$ & $\begin{array}{c}\text { 最大輝度 } \\
\text { (nt) }\end{array}$ & & 一ク值 & 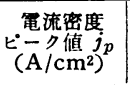 & $\begin{array}{c}j_{p} / p^{2} \\
\left(\mathrm{~mA}^{2} / \mathrm{cm}^{2}\right. \\
\left.\text { Torr }^{2}\right)\end{array}$ & $j_{p} / p_{4}$ \\
\hline 64 & 500 & & 5 & 2.24 & 0.55 & 6.63 \\
\hline 32 & 250 & & 2 & 0.9 & 0.88 & 7. 03 \\
\hline 16 & 150 & & 0.7 & 0.32 & 1. 25 & 6.60 \\
\hline
\end{tabular}

$2 \mathrm{R}=1.95 \mathrm{~cm}, \mathrm{~L}=10 \mathrm{~cm}, \mathrm{Al}$ 電極, 周囲温度: $15^{\circ} \mathrm{C}$

菓源電压: $1 \mathrm{kV}, \mathrm{f}=100 \mathrm{~Hz}, \quad=300 \mu \mathrm{s}$, ヘ形バルス

\section{（3）放電電流（輝度）の上限}

電極面積の項で述べたように, 陰極電流密度には上限があり, その值は $\mathrm{Ne}$ の封入圧で決まる. 表 2 にその実測例を示す. こ の上限は拉よそ封入圧の 1.4 乗に比例しており，封入圧の大きい ほど輝度を大きくできる.

\section{(4) 放軋開始電圧}

放電開始電圧は， Ne 封入圧の増大とともに大きくなる傾向は あるが，常温付近ではその影響は比較的小さいので，電源電圧の 選定にはさほど影響しない。 


\subsubsection{Hg 蒸気圧（管壁温度）}

放電管には $\mathrm{Hg}$ が十分多量に封入されているので, $\mathrm{Hg}$ 蒸気圧 は管壁温度によって変動する. $\mathrm{Hg}$ 蒸気仕は放電開始電圧, 負グ ローの厚さだけでなく発光色にも影響を及ぼす，極端な場合には 変色が不能となったり(低温), 可変色そのものが異質となる(高 温）こともある ${ }^{2)}$. 放電管はけい光灯などと同様, 特に温度管理 せずに使用するのが通常であるから，温度特性を無視することは できない。しかし，放電開始電圧は常温付近で泳最小となり， 発光色も常温付近が最も良い. 本論文では温度は常温付近に保 ち，温度特性およびその補償法については省略する。

\section{2 点灯回路に係わる因子}

点灯時に, 放電管に合わせて回路側で選定する因子には, 電源 電压, 放電電流, 繰返し周波数, パルス幅の四つがある.

\section{2.1 電 源 電 圧}

使用する電源の電圧は，放電開始電圧以上でなければならない のは当然であるが, 放電が可変色となるための電圧は通常, 開始 電圧より相当大きい，電源電圧による発光色の变化の一例を図 8 に示す. 繰返し周波数を $150 \mathrm{~Hz}$ ，パルス幅を150 $\mu \mathrm{s}$ ，輝度を $50 \mathrm{nt}$ にそれぞれ保ち，電源電圧を $400 \mathrm{~V} か ら ~ 1 \mathrm{kV}$ まで变化させた. 形パルスによる放電の発光色は, 電源電圧によらず一定（青）で ある・

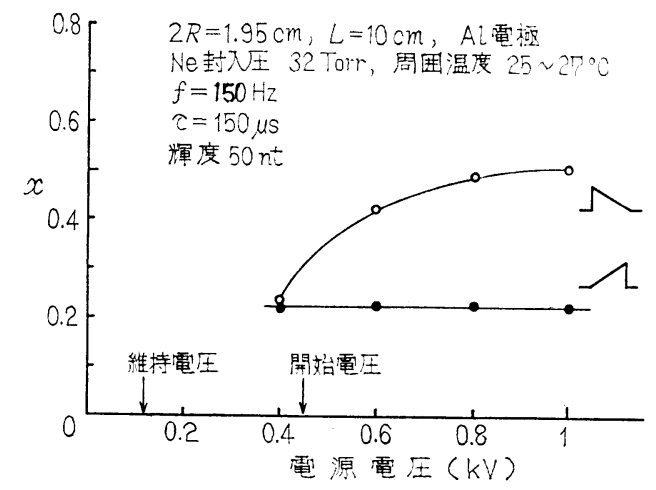

图 8 電源䉓代による発光色の变化

一方, 人形パスの場合には, 電源電圧の変化に伴ってその発 光色が大きく変化している. 図は放電開始電圧 $450 \mathrm{~V}$, 維持電压 $170 \mathrm{~V}$ の場合であるが，放電開始後電源電圧をいったん下げて $400 \mathrm{~V}$ とした場合には，ノ形パルスによる発光色とほとんど同じ （青色）である. 電圧の上昇とともに赤色が強くなり，やがて一。 定となる. 発光色が赤色となるためには，パルスの立ち上がり時 に大きな電界が必要である. そのために電源電纴は放電開始電圧 よりある程度大きくなければならないと考えられる。電源電圧は あまり大きくしても効果はなく，両パルスによる発光色の色度差 が十分な大きさになるように設定すればよく，図の例では $800 \mathrm{~V}$ 以上であればよい，開始電圧と必要電源電圧の差は管径が細い場 合は小さく，太くなるほど大きくなる傾向がある.

\section{2 .2 放電電流 (輝度)}

陽光柱の輝度は放電電流（平均值）で調節する，極端に輝度の 小さい場合を除き発光色にはさほど大きな影響はない，ただし， 実験用の放電管には Hg 十分多量にはいっているので，電流を大 きくしていくと管壁温度が上昇し, $\mathrm{Hg}$ 蒸気圧が増大して発光色 に影響を及ぼすことがある.

5.2.3 パル ス

繰返し周波数を $150 \mathrm{~Hz}$ 一定にしておいて，パルス幅を変えた
ときの発光色の変化を図 9 に示す. 人形パルスによる発光色は $15 \mu \mathrm{s}$ から $1 \mathrm{~ms}$ までの広い範囲にわたってほとんぞ一定（赤色） であり，1 ms を超えると青色に向かっていく，一方， イ形パル スの場合にはパルス幅が狭いと赤色が強く，15 $\mu \mathrm{s}$ ではほとんど 人形パルスと同じであるが，幅を広くするにつれて青色が強くな り，150 $\mu \mathrm{s}$ 以上では汪とんど一定（青色）となる，両パルスによ る発光色の色度差は, $150 \mu \mathrm{s}$ から $1 \mathrm{~ms}$ までの広い範围にわたっ て一定になるので，パルス幅の值はこの範囲から任意に選べるこ とになる．電極をマトリックス状に配置するディスプレイパネル では $T / \tau$ が掃引行数の上限となるので，ては小さいほうが望 ましいが，単一放電管では特別問題とならない、図の管径 1.95 $\mathrm{cm} \phi$ の場合，ては最小 $150 \mu \mathrm{s}$ でよかったが，管径がこれより小 さい場合 $\tau$ はもう少し広いほうがよく, 温度の低い場合も広めが 良いので, 単一放電管では300 $\mu \mathrm{s}$ 程度にして打けば, ほとんどの 場合に適合する.

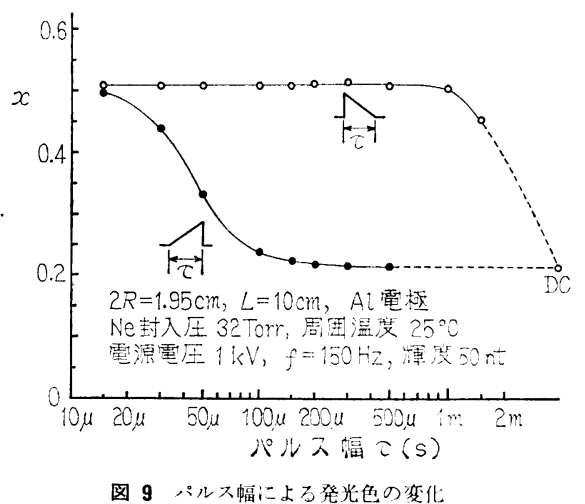

\section{2.4 繰返し周波数 (周期)}

パスの立ち上がり時間だけによって発光色を制御する方式で

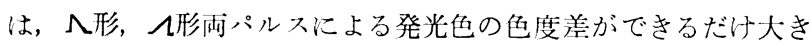
いことが望ましい，そのためには絽返し周波数を適切な值に設定 することが最も重要となる. $1 \mathrm{~cm} \phi$ か $4.7 \mathrm{~cm} \phi$ までの 4 種類 の管径の放電管を使用し，パルス幅を $150 \mu \mathrm{s}$ 一定とし，周波数を $40 \mathrm{~Hz}$ から $2 \mathrm{kHz}$ まで変化させたときの発光色の変化の様子を 図 10 に示す. 人形パルスによる発光色は, 管径の大きい放電管 では周波数に対してほとんど変動しないが，管径の小さい放電管 では周波数が低くなると $\mathrm{Ne}$ の発光がみられるようになり，白っ ぽくなる傾向がある.一方入形パルスによる発光色は, 周波数の 低いところでは赤色であるが，周波数が高くなるにつれて青色に 向かい，遂にはへ形パルスによる発光色と同じになってしまう。

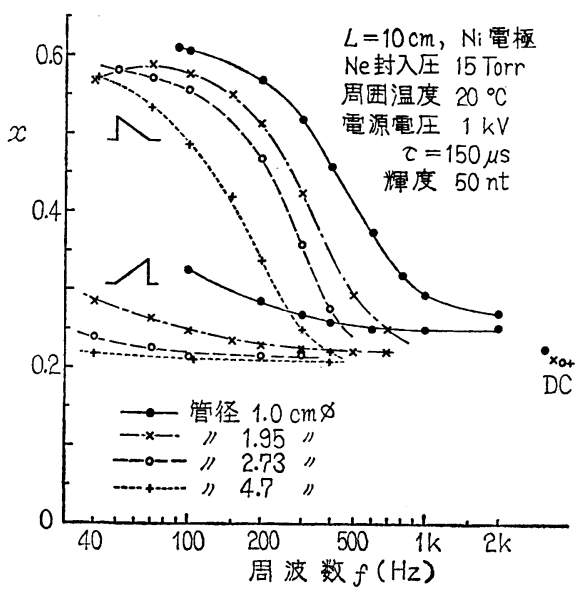

图 10 繰り返し周波数と発光色の関係 
この発光色 - 周波数曲線 $(x-f$ 曲線) に関して興味深いのは どの管径についても曲線の形はほとんど同じで，ただ管径によっ て周波数が平行移動しているということである.つまり管径が小 さくなると曲線が周波数の高いほうへ移動していくのである.

各管径に対する最適周波数は，両パルスによる発光色の色度差 が最大となる周波数を求めるのが基本となる.

CIE 1931 標準色度図 ( $(x, y)$ 色度図) 上で表わされる二つ の色度点間の距離は，感覚的な色の性質の差に比例しない， CIE では，感覚的により均等な色間隔を問題とする場合には， CIE UCS 色度図 ( $(u, v)$ 色度図) を用いることを推奖している. そこで，今問題にしている両パルスの色度差を（u，v）色度図 上での距離で表わすことにする．人形，人形パルスに対する発光 色の座標をそれぞれ， $\left(\boldsymbol{u}_{r}, v_{r}\right),\left(\boldsymbol{u}_{b}, v_{b}\right)$ とし，その 2 点間の 距離を $\Delta w$ とすれば, $\Delta w=\left\{\left(u_{r}-u_{b}\right)^{2}+\left(v_{r}-v_{b}{ }^{2}\right\}^{1 / 2}\right.$ となる. こ の $\Delta w$ をもって色度差とする.

図10の実験結果を $(u, v)$ 色度図に移し替えて $\Delta w$ を求め, その周波数注対する変化を図 11 に示す. $\Delta w-f$ 曲線も $x-f$ 曲 線と同様に管径によって周波数が移動している. $\Delta w$ の最大值付 近では曲線は比較的平担であるから，適性周波数には多少の幅が 許される. そこで，最終的に最適周波数を求めるには実際に点灯 し， $\Delta w$ の最大となる周波数の前後で，赤・青双方の発光色が目 で見て良い色となる周波数を探し出すことになる.

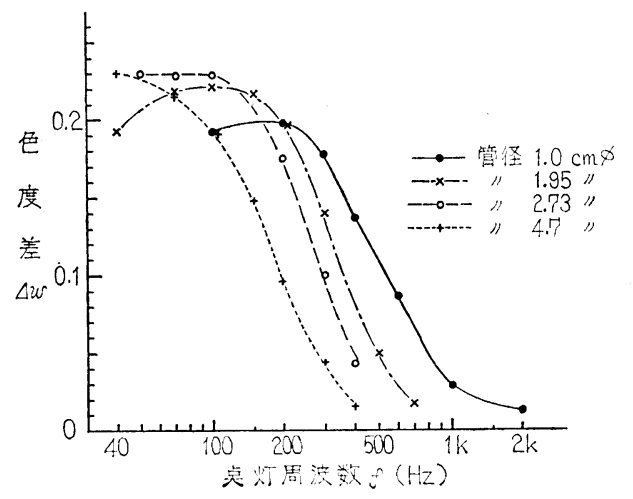

図 11 形, 1 形両ハルスによる発光色の差異 $\Delta w$

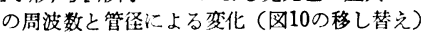

各管径に対する最適周波数は, 温度 $20^{\circ} \mathrm{C}$ の場合, $4.7 \mathrm{~cm} \phi$ で 技よそ $40 \mathrm{~Hz}, 2.73 \mathrm{~cm} \phi$ で70 Hz 前後, $1.95 \mathrm{~cm} \phi$ で $100 \mathrm{~Hz}$ 前 後, $1 \mathrm{~cm} \phi$ で $210 \mathrm{~Hz}$ 前後である. また, 別の目測奏験では 0.5 $\mathrm{cm} \phi$ に対して扰よそ $450 \mathrm{~Hz}$ といら結果も得ている.これらの結 果から, 内径 $2 R(\mathrm{~cm})$ の放電管に対する最適周波数 $f(\mathrm{~Hz})$ は, 史験式

$$
f \simeq 210 \cdot(2 R)^{-1.1} \quad(\mathrm{~Hz})
$$

で表わすことができ， $0.5 \sim 5 \mathrm{~cm} \phi$ の放電管に対して点灯実験と よく合致する．前述のように周波数には多少の幅が許されるの で,

$$
f \simeq 210 /(2 R) \quad(\mathrm{Hz})
$$

としても実用上はほとんど問題ない.

\section{6. 考 察}

可変色放電に関するパラメータについて実験結果を述べてきた が, これらのらち応用上重要なものについて若干の考察を加兑 る.

\section{(1) Ne 封入圧について}

この可変色放電は利用する立場からは，陽光柱だけが有効であ る. 陰極は全面負グローでおおわれて赤色だけを示し，いわゆる 異常グロー放電であるので, 負グローの厚さは薄いほどよい，一 般に負グローの厚さは，正規グロー・異常グロー共に $p^{3}$ に逆比 例するといわれているが4)，これは直流放電の場合である. 表 1 の実測值によれば，およそpの 2 乗強に逆比例しており，パルス 放電であることを考えると一応妥当な傾向であるといえよう.

\section{(2) 管径 $2 \boldsymbol{R}$ と最適周波数 $\boldsymbol{f}$ の間の関係について}

管径一定として，最適周波数より高い周波数では赤が出にく く，より低い周波数では赤は出やすいかわりに青が出にくくな る. このことは, 可変色に都合のよいパルス休止時間の存在を示 しており，残留イオンの最適值を与えるパルス間隔によって，最 適周波数が決まるであるらことを暗示している。

軸方向に一様な陽光柱では，(2)式を変形することにより， $f=\frac{210}{2 R}=52.5 \times \frac{2 \pi R}{\pi R^{2}}=52.5 \times \frac{\text { 断面の周辺長 }(\mathrm{cm})}{\text { 放電管断面積 }\left(\mathrm{cm}^{2}\right)}(\mathrm{Hz})$

と考えてみることができる，ここで断面が円形ではなく， $a(\mathrm{~cm})$ $\times b(\mathrm{~cm})$ の矩形の放電管に対して上式を適用してみると,

$$
f=52.5 \times \frac{2(a+b)}{a b} \quad(\mathrm{~Hz})
$$

となる. 筆者らは $1.5 \mathrm{~cm} \times 4.6 \mathrm{~cm}$ の放電管を試作したが, (4)式 によれば， $f \fallingdotseq 93(\mathrm{~Hz})$ となる。この值は実験して得られた最適 周波数が拈よそ90(Hz) であることとよく一致している.

以上のことから，断面の形が軸方向に一定な放電管の最適周波 数は㬰験的に $f=52.5 \times$ (断面周辺長 /断面積)としてょいとい える。

パルス休止期間中に放電空間から消えていくイオンは, 再結合 を無視すれば軸方向に一様で十分長い陽光柱では，

$$
\frac{d \bar{n}}{d t}=\frac{S}{V} \Gamma=\left(\frac{\text { 周辺長 }}{\text { 断面積 }}\right) \bar{n} u
$$

と表わすことができる.ここで， $\bar{n}$ はイオンの空間平均密度， $u$ はイオンの等価流失速度, $V$ は放電空間の体積, $S$ はその表面 積, $\Gamma$ は $S$ から出ていくイオン流束である.

この系の時定数は $V / S=\Lambda$ とおいて, $\tau \approx \Lambda / u$ となる.拡散理 論に従うとすれば $u \approx D / \Lambda$ ( $D$ は拡散係数）であるから，最適周 波数は $f \approx D / \Lambda^{2}$ となるはずであるが，これは実験と合わない。 $u$ が $\Lambda$ によらないと仮定すれば， $f \Lambda=$ constとなり，聿験結果を 一応説明できるが，この仮定の成立については別途吟味する必要 がある.

\section{(3) ディスプレイパネルの構成について}

画像の分解能は画素径で決まり，掃引可能行数は $T / \tau$ で決ま る. ところが画素径 $(2 R)$ と周波数 $f$ の間には $f \simeq 210 /(2 R)$ の関係があるから, 掃引可能行数 $N_{m}$ は

$$
N_{m}=T / \tau=1 / f \cdot \tau=(2 R) / 210 \cdot \tau
$$

で表わされる．パルス幅 $\tau$ を $300 \mu \mathrm{s}$ とすれば， $N_{m} \simeq 16(2 R)$ と なる．この $N_{m}$ より行数の多いパネルを作る場合は， $N_{m}$ 行を 単位としたパネルをいくつか並べて構成することになる．画素が 大きいほど掃引行数の多いパネルが作れる.

\section{(4) 駆動回路について}

今後この制御方式により, 可変色放電の実用化を進めていく上 で, 回路的に問題になると考えられるのは次の点である.

(a) 高圧直流電源を必要とする上に, 三角波の立ち上がりを変 
えるので回路がやや複雑となり，装置全体が大がかりとなる.

(b) 制御トランジスタを線形領域で使用するので, コレクタ損 失が大きくなり，トランジスタの負担が大となる.

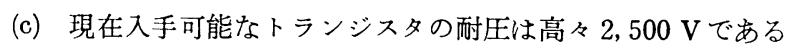
ので，ネオンサインのような長い放電管は制御できない.

これらの問題点に対しては種々の解決法が考えられ, 筆者らは 引き続き基礎実験を行なって扣り，近い機会に稿を改めて報告す る予定である.

\section{7. むす び}

放電の発光色を電子的に制御する方法として，パルスの立ち上 がり時間を利用することを試み，周波数とパルス幅を一定とした まま陽光柱の発光色を $\mathrm{Hg}$ の青色から $\mathrm{Ne}$ の赤色付近まで連続的 に変えられることを実証した。

可変色放電の設計に際して, 放電諸因子をどのような值に設定 すべきかについては次のことが明らかとなった。

（1） Ne 封入压は十〜数十 Torr であれば，可変色放電管とし て使用できる．発光色は压力の低いほうが良いが，負グローを薄 くしたい場合，および輝度を大きくしたい場合には圧力が高いほ らがよい。

（2）電源電圧は赤色が十分発光できる值に選ぶ．この值は一般
に放電開始電圧より大きい.

(3) パルス幅は $150 \mu \mathrm{s} \sim 1 \mathrm{~ms}$ であればよいが, $300 \mu \mathrm{s}$ ぐらい にしておけばほとんどの場合に適合できる.

(4) 繰返し周波数は， $f \simeq 210(2 R)^{-1.1}$ とすればよい，実用 的には $f \simeq 210 /(2 R)$ としてよい.

この制御方式により, 可変色放電を放電ディスプレイパネルに 応用できる見通しとなった．筆者らは基礎実験によりそれが可能 であることを確かめており, その方面の研究をも進めつつある.

今回は放電ガスとして $\mathrm{Hg} ・ \mathrm{Ne}$ の混合気体を用いた。この方 法は原理的に, 負グローと陽光柱で発光色を異にするいかなる単 一または混合気体に対しても適用できることはいうまでもない。

おわりに, 本研究に対しご協力いただいた明石高専電気工学科 鍛治幸悦教授に深謝します。

参 考 文 献

（1）青野, 久保, 板谷：照学誌 60-10（昭51） 529 536

(2) 竜子ほか：電気学会光源関連装置研究会資料 LS-78-2，3 (昭53)

（3）竜子ほか：照明学会全国大会講演論文集 23（昭54）

(4) 野畑：電学誌 81 (昭36) 155

（受付1981年 4 月 30 日）

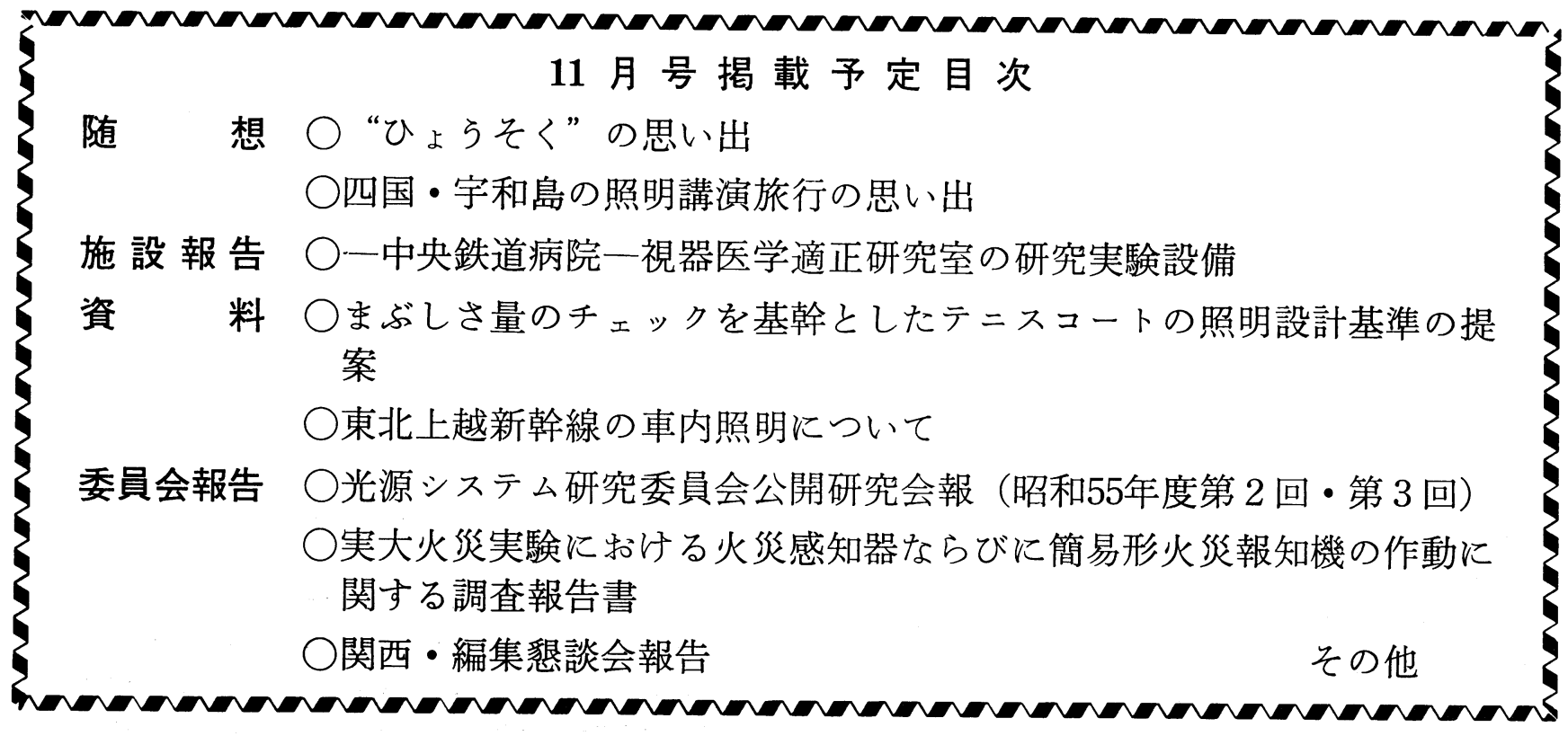

